\title{
Dry reforming of methane: Influence of process parameters-A review
}

Muhammad Usman ${ }^{\text {a }}$, W.M.A. Wan Daud ${ }^{\text {a,* }}$, Hazzim F. Abbas ${ }^{\mathrm{b}}$

${ }^{a}$ Department of Chemical Engineering, University of Malaya, 50603 Kuala Lumpur, Malaysic

${ }^{\mathrm{b}}$ Department of Chemical Engineering, University of Nizwa, Al Dakulaya, Oman

A R T I C L E I N F O

Article history:

Received 17 June 2014

Received in revised form

23 September 2014

Accepted 7 February 2015

Available online 27 February 2015

Keywords:

Dry reforming of methane

Landfill gas

Syn-gas

Carbon deposition

Ni catalyst

\begin{abstract}
A B S T R A C T
This review will explore the influences of the active metal, support, promoter, preparation methods, calcination temperature, reducing environment, partide size and reactor choice on catalytic activity and carbon deposition for the dry reforming of methane. Bimetallic ( $\mathrm{Ni}-\mathrm{Pt}, \mathrm{Ni}-\mathrm{Rh}, \mathrm{Ni}-\mathrm{Ce}, \mathrm{Ni}-\mathrm{Mo}, \mathrm{Ni}-\mathrm{Co}$ ) and monometallic $(\mathrm{Ni})$ catalysts are preferred for dry reforming compared to noble metals (Rh, Ru and Pt) due to their low-cost. Investigation of support materials indicated that ceria-zirconia mixtures, $\mathrm{ZrO}_{2}$ with alkali metals $\left(\mathrm{Mg}^{2+}\right.$ $\mathrm{Ca}^{2+}, \mathrm{Y}^{2+}$ ) addition, $\mathrm{MgO}, \mathrm{SBA}-15, \mathrm{ZMM}-5, \mathrm{CeO}_{2}, \mathrm{BaTiO}_{3}$ and $\mathrm{Ca}_{0.8} \mathrm{Sr}_{0.2} \mathrm{TiO}_{3}$ showed improved catalytic activities and decreased carbon deposition. The modifying effects of cerium $(\mathrm{Ce})$, magnesium $(\mathrm{Mg})$ and yttrium $(\mathrm{Y})$ were significant for dry reforming of methane. $\mathrm{MgO}, \mathrm{CeO}_{2}$ and $\mathrm{La}_{2} \mathrm{O}_{3}$ promoters for metal catalysts supported on mesoporous materials had the highest catalyst stability among all the other promoters. Preparation methods played an important role in the synthesis of smaller particle size and higher dispersion of active metals. Calcination temperature and treatment duration imparted significant changes to the morphology of catalysts as evident by XRD, TPR and XPS. Catalyst reduction in different environments $\left(\mathrm{H}_{2}, \mathrm{He}, \mathrm{H}_{2} / \mathrm{He}, \mathrm{O}_{2} / \mathrm{He}, \mathrm{H}_{2}-\mathrm{N}_{2}\right.$ and $\mathrm{CH}_{4} / \mathrm{O}_{2}$ ) indicated that probably the mixture of reducing agents will lead to enhanced catalytic activities. Smaller particle size $(<15 \mathrm{~nm}$ ) had a significant influence on the suppression of carbon deposition and catalytic activity. Fluidized bed reactor exhibited the highest activity and stability, lower carbon deposition and higher conversion compared to a fixed-bed reactor. Moreover, membrane reactor, solar reactor, high-pressure reactor and microreactor were also investigated with specific features such as: pure $\mathrm{H}_{2}$ production, detailed reaction information with enhanced safety, higher pressure applications and dry reforming reaction with/ without catalyst under sunlight. The study of parameters would improve the understanding of various preparation and reaction conditions leading to various catalytic activities.
\end{abstract}

2015 Elsevier Ltd. All rights reserved.

Contents

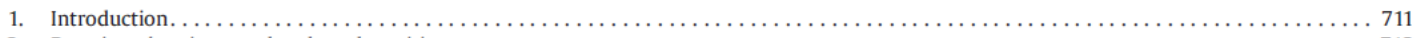

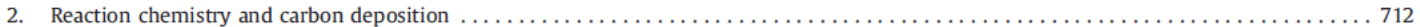

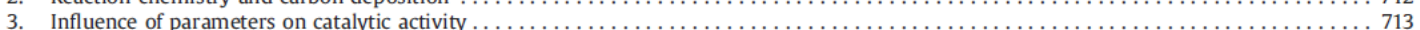

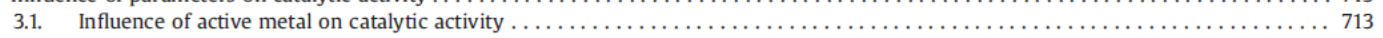

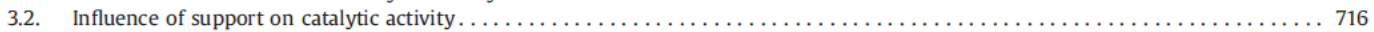

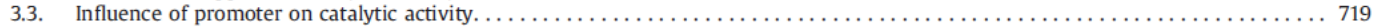

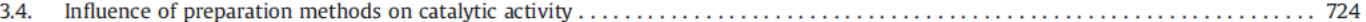

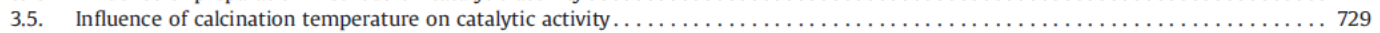

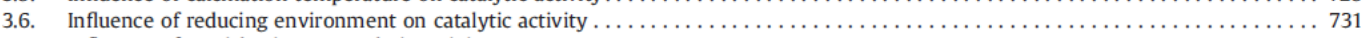

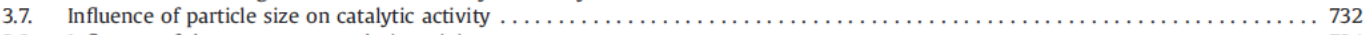

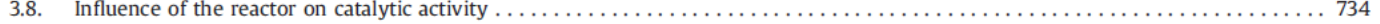

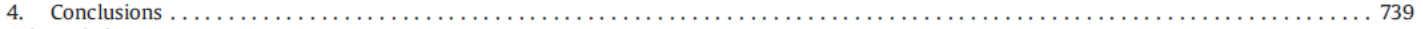

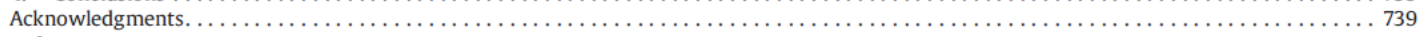

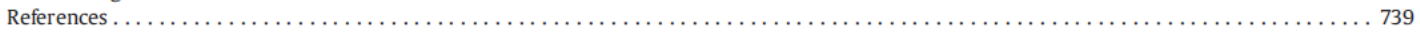

\footnotetext{
*Corresponding author. Tel.: +60 379675297; fax: +60 379675319.

E-mail address: ashri@um.edu.my (W.M.A. Wan Daud).

http://dx.doi.org/10.1016/j.rser.2015.02.026

$1364-0321 / \odot 2015$ Elsevier Ltd. All rights reserved.
} 


\section{Introduction}

Rapid increase in population and high-energy consumption has been forecasted over the years [1]. Growing human demands have shifted the energy scenario over the years by industrialization [2] and energy demand will increase 57\% from 2004 to 2030 [3]. The dependence on fossil fuels to meet energy demand has created environmental issues by the production of greenhouse gases (GHG) [4]. Methane and carbon dioxide constitute a major part of GHG and have the key contributions in climate-change [5], forecasted in terms of greater incidence and magnitude of hurricanes, floods, and droughts [6], affecting productivity, natural ecosystems, agriculture, rangelands, forestry and society $[7,8]$. An increase of $0.8^{\circ} \mathrm{C}$ in global surface temperature occurred in the 20th century and further increase $\left(1.4-5.8^{\circ} \mathrm{C}\right)$ has been anticipated in twenty-first century $[6,8]$. The concentrations of methane and carbon dioxide in 2011 were 1.813 and $390.5 \mathrm{ppm}$, respectively, based on the assessment of the World Meteorological Organization (WMO) [9]. Even though the concentration of methane in the atmosphere was lower than carbon dioxide $[10,11]$, it kicked in about $20 \%$ of overall global warming $[12,13]$. Two sources of methane emission were identified, firstly: from naturally occurring activities such as: termites, grasslands, coal beds, lakes, wetlands and wildfires and secondly: from anthropogenic activities such as: landfills, oil and gas processing, wastewater treatment plants, coal mining, rice production, cattle ranching and agricultural activities [14]. Methane was estimated to

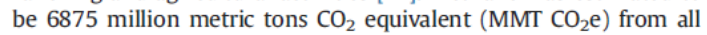
anthropogenic sources in 2010 [15].

Methane is a major component of natural gas (NG) and also contains low balances of other hydrocarbons comprised on ethane $\left(\mathrm{C}_{2} \mathrm{H}_{6}\right)$, propane $\left(\mathrm{C}_{3} \mathrm{H}_{8}\right)$, and butane $\left(\mathrm{C}_{4} \mathrm{H}_{10}\right)$. NG also contains inert diluents such as molecular nitrogen $\left(\mathrm{N}_{2}\right)$ and carbon dioxide $\left(\mathrm{CO}_{2}\right)$ [16]. The majority of NG reservoirs are located far from industrial complexes and often produced offshore. The transportation of NG to potential market by pipelines may not be available and liquefaction for shipping purpose by an ocean-going vessel is expensive [17]. In 2011, large volume of NG (140 billion cubic meters, (BCM)) has been flared globally and the flaring data for the top 20 nations have been shown in Fig. 1 in which Russia has the highest share in the global flaring data [18]. Two disadvantages occurred from flaring, first: the wastage of an important hydrocarbon source worth billions and second: global warming by the production of GHG [19].

The population growth has resulted in the increased rate of waste generation and improper handling of waste created environmental issues [5]. In 2012, a study reported that currently there are about 3 billion urban resident generating $1.2 \mathrm{~kg}$ per person per day ( 1.3 billion tonnes per year) and it is estimated that in 2025 it will be likely to rise up to 4.3 billion residents generating $1.42 \mathrm{~kg}$ per person per day which will produce 2.2 billion tonnes per year [20]. Moreover, for developed countries, the rate of the increase was estimated to be $3.2-4.5 \%$ and for developing nations around $2-3 \%$ [21]. The disposal of MSW in the landfills lead to the generation of methane by anaerobic degradation of the organic content in the waste and biogas has been expected at different rates by various management methods employed [22]. Production of methane from landfill, constitute a major portion of all emitted methane in the US (about one third) [23]. Landfill gas consists of $40-45 \%$ methane and $55-60 \%$ carbon dioxide by volume [24] while some predicted $50-60 \%$ and $30-40 \%$ by volume of methane and carbon dioxide [25], respectively.

Keeping in view the above scenario, extensive research is being performed to convert methane into liquid fuels or higher hydrocarbons [26]. The researchers were investigating the production of methanol, formaldehyde, propanol, benzene and other aromatics by direct oxidative conversion of methane. Unfortunately, all the aforementioned processes have low yields or are unfeasible on an industrial-scale [27]. Various technologies are available to produce synthesis gas (syn-gas) from NG [28], as syn-gas is a building block for valuable liquid fuels and chemicals such as Fischer-Tropsch oil, methanol and dimethyl ether $[17,29,30]$. The three processes that draw industrial attention are steam reforming of methane (1), partial oxidation of methane with oxygen or air (2) and dry reforming of methane with carbon dioxide (3) [31].

$\mathrm{CH}_{4}+\mathrm{H}_{2} \mathrm{O} \rightarrow \mathrm{CO}+3 \mathrm{H}_{2} \quad \Delta H_{298 \mathrm{~K}}^{0}=225.4 \mathrm{~kJ} / \mathrm{mol}$

$\mathrm{CH}_{4}+1 / 2 \mathrm{O}_{2} \rightarrow \mathrm{CO}+2 \mathrm{H}_{2} \quad \Delta H_{298 \mathrm{~K}}^{0}=-22.6 \mathrm{~kJ} / \mathrm{mol}$

$\mathrm{CH}_{4}+\mathrm{CO}_{2} \rightarrow 2 \mathrm{CO}+2 \mathrm{H}_{2} \quad \Delta H_{298 \mathrm{~K}}^{0}=260.5 \mathrm{~kJ} / \mathrm{mol}$

Reforming of methane through steam or partial oxidation of methane with oxygen or air are well-established technologies with the advantages and disadvantages $[32,33]$. Steam reforming of methane produces a higher ratio of syn-gas $\left(\mathrm{H}_{2} / \mathrm{CO}=3\right)[34]$ compared to that required for Fischer-Tropsch or methanol synthesis $\left(\mathrm{H}_{2} / \mathrm{CO}=2\right)[35,36]$. The process is energy intensive due to the endothermic nature and requires high investments of capital [37]. A higher $\mathrm{H}_{2} \mathrm{O} / \mathrm{CH}_{4}$ ratio is required to produce higher yields of hydrogen, which makes steam reforming of methane energetically unfavorable leading to the deactivation of the catalyst [38]. Moreover, steam reforming faces corrosion issues and requires a desulphurization unit $[32,33]$. Partial oxidation of methane is suitable for the production of heavier hydrocarbons and naphtha $[32,39]$. The advantages of this process are high conversion rates, high selectivity and very short residence time [40]. The exothermic nature of reaction has certain drawbacks that it induces hot spots on catalyst arising from poor heat removal rate and makes operation difficult to control $[31,33]$. Desulphurization unit is not required in the partial oxidation of methane [33], but a cryogenic unit is necessary for the separation of oxygen from air [32].

Dry reforming of methane offers valuable environmental benefits: biogas utilization [41,42], removal of GHG (methane and carbon dioxide) and conversion of NG with a high carbon dioxide content to valuable syn-gas $[17,26]$. Dry reforming of methane yielded a lower syn-gas ratio $\left(\mathrm{H}_{2} / \mathrm{CO}=1\right)$, which is suitable for the synthesis of oxygenated chemicals [43] and hydrocarbons from Fischer-Tropsch synthesis [35]. Syn-gas from dry reforming has also been considered for storage of solar or nuclear energy [44-46] through the chemical energy transmission system (CETS). Solar energy can convert feed gases (methane and carbon dioxide) to syn-gas that can be exported to places where energy sources are scarce. The energy stored in syn-gas is liberated by the backward reaction and utilized as an energy source [46].

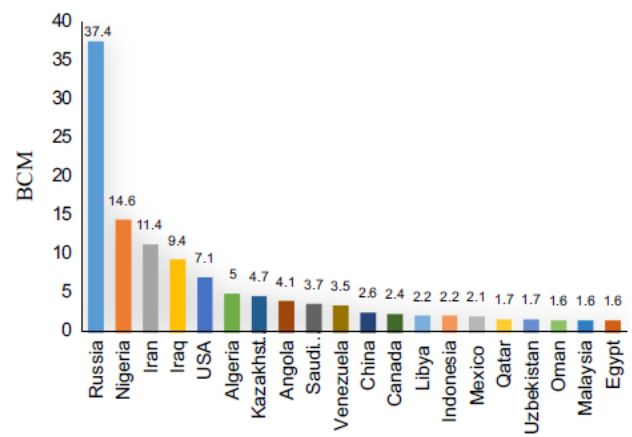

Fig. 1. Global natural gas flaring data [18]. 


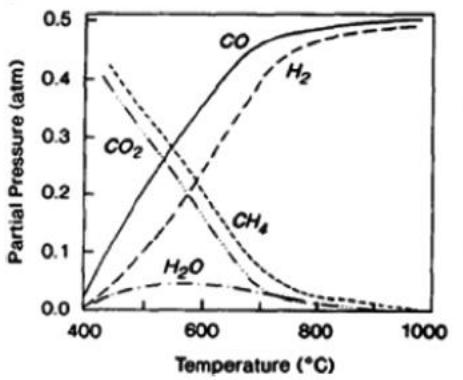

b

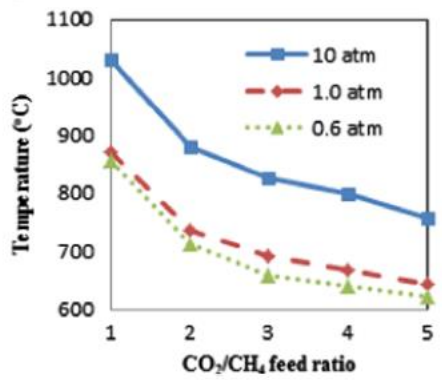

Fig. 2. (a) Equilibrium gas composition of $\mathrm{CO}_{2} / \mathrm{CH}_{4}$ (1:1) and $1 \mathrm{~atm}$ [46]; (b) effect of $\mathrm{CO}_{2} / \mathrm{CH}_{4}$ feed ratio on carbon deposition limit temperature at various pressures [51].

\section{Reaction chemistry and carbon deposition}

The production of syn-gas from dry reforming of methane is influenced by the simultaneous occurrence of reverse water gas shift (RWGS) reaction (4) resulting in a syn-gas ratio less than unity [26].

$\mathrm{CO}_{2}+\mathrm{H}_{2} \rightarrow \mathrm{CO}+\mathrm{H}_{2} \mathrm{O} \quad \Delta H_{298 \mathrm{~K}}^{0}=41.0 \mathrm{~kJ} / \mathrm{mol}$

Dry reforming of methane despite having environmental benefits suffers from the carbon deposition problem induced by methane decomposition (5) and CO disproportionation or Boudouard reaction (6).

$\mathrm{CH}_{4} \rightarrow \mathrm{C}+2 \mathrm{H}_{2} \quad \Delta H_{298 \mathrm{~K}}^{0}=75.0 \mathrm{~kJ} / \mathrm{mol}$

$2 \mathrm{CO} \rightarrow \mathrm{C}+\mathrm{CO}_{2} \quad \Delta H_{298 \mathrm{~K}}^{0}=-172.0 \mathrm{~kJ} / \mathrm{mol}$

The tendency towards carbon deposition can be estimated by the ratio of $\mathrm{O} / \mathrm{C}$ and $\mathrm{H} / \mathrm{C}$ in the feed gas. The higher tendency towards carbon deposition will be observed in lower $\mathrm{O} / \mathrm{C}$ and $\mathrm{H} / \mathrm{C}$ ratio [28], which is the case in dry reforming of methane $\left(\mathrm{CH}_{4} / \mathrm{CO}_{2}=1 / 1\right)$ having $\mathrm{O} / \mathrm{C}=1$ and $\mathrm{H} / \mathrm{C}=2$. Reverse case was observed for steam reforming of methane $\left(\mathrm{CH}_{4} / \mathrm{H}_{2} \mathrm{O}=1 / 1\right)$ having high $\mathrm{O} / \mathrm{C}=1$ and $\mathrm{H} / \mathrm{C}=6$ [30]. Similarly, partial oxidation of methane $\left(\mathrm{CH}_{4} / 0.5 \mathrm{O}_{2}\right)$ showed a quite higher ratio, $\mathrm{O} / \mathrm{C}=1$ and $\mathrm{H} / \mathrm{C}=4$. Considering the aforementioned ratios, it was clear that dry reforming of methane has a higher tendency towards carbon deposition compared to steam reforming and partial oxidation of methane [47]. Thermodynamic studies on dry reforming reaction revealed that spontaneous reaction cannot be achieved below $640{ }^{\circ} \mathrm{C}$ [48] and the side reactions (5) and (6) took place at a significant rate between 633 and $700{ }^{\circ} \mathrm{C}$. Therefore, a higher temperature $\left(T \geq 700{ }^{\circ} \mathrm{C}\right)$ was empl ${ }^{\circ}$ yed to minimize the effect of side reactions, which lead to reactor blockages and reduction in activity $[49,50]$.

Djinović et al. [32] reported little higher temperature than the previously mentioned. They proposed that to minimize the effect of RWGS (4) and increase $\mathrm{H}_{2}$ yield, a higher temperature $\left(>750{ }^{\circ} \mathrm{C}\right.$ ) or a higher ratio of $\mathrm{CH}_{4} / \mathrm{CO}_{2}(>1)$ should be used [32]. However, a higher ratio of $\mathrm{CH}_{4} / \mathrm{CO}_{2}$ created operational complexities such as an increased amount of carbon deposition [26], and the need for a separation system downstream to collect and recycle the surplus methane [32]. The reforming of methane at $1 \mathrm{~atm}$ and $\mathrm{CO}_{2} / \mathrm{CH}_{4}=1$ (Fig. 2a) assumed that reacting mixture was in equilibrium regarding the reactions from (4)-(6). The formation of water $\left(<900^{\circ} \mathrm{C}\right)$ from the reaction (4) resulted in lower $\mathrm{H}_{2}$ yield compared with $\mathrm{CO}$, while at $900{ }^{\circ} \mathrm{C}$, methane conversion reached $97 \%$ and production of water becomes negligible after $900{ }^{\circ} \mathrm{C}[46]$. The temperature limits for carbon deposition were also investigated (Fig. $2 \mathrm{~b}$ ) with respect to pressure $(0.6$ $1,10 \mathrm{~atm})$ and feed gas ratio $\left(\mathrm{CO}_{2} / \mathrm{CH}_{4}\right)$ [51]. When the reforming

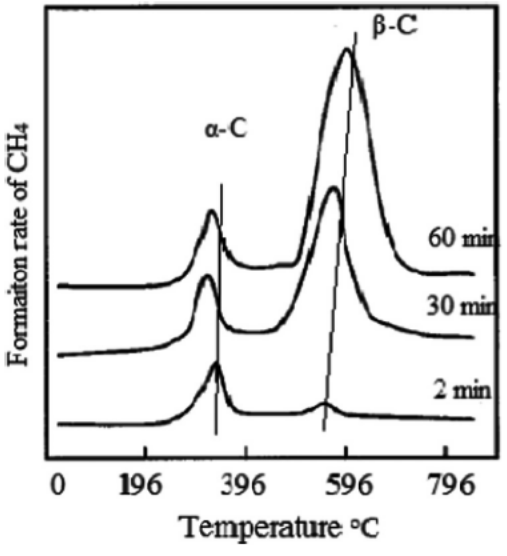

Fig. 3. TPH profiles for $3 \mathrm{~mol} \% \mathrm{Ni} / \mathrm{MgO}$ catalyst at different contact times ( $2 \mathrm{~min}$, $30 \mathrm{~min}$ and $60 \mathrm{~min})[53]$

reaction was performed at $1 \mathrm{~atm}$ and $\mathrm{CO}_{2} / \mathrm{CH}_{4}=1$, carbon deposition was unavoidable at temperatures lower than $870{ }^{\circ} \mathrm{C}$. The rise of pressure from $1 \mathrm{~atm}$ to $10 \mathrm{~atm}$ lead to the increased carbon deposition limit from $870{ }^{\circ} \mathrm{C}$ to $1030{ }^{\circ} \mathrm{C}$, which confirmed that for the same feed ratio, an increase in pressure will increase the temperature limit for carbon deposition. Moreover, decreasing $\mathrm{CO}_{2} / \mathrm{CH}_{4}$ ratios at a constant pressure also increased the temperature limit for carbon deposition (Fig. 2b) [51].

Different types of carbon were produced during the dry reforming of methane. $\mathrm{Ni} / \mathrm{Al}_{2} \mathrm{O}_{3}$ exhibited three types of carbonaceous species denoted as $\alpha-C, \beta-C$, and $\gamma$-C. It was suggested that $\alpha$ $C$ assisted in the formation of $\mathrm{CO}$, while less active carbon types ( $\beta$ $\mathrm{C}$ and $\gamma-\mathrm{C}$ ) leads to the deactivation of the catalyst [52]. Temperature programmed hydrogenation (TPH) of Ni/MgO (Fig. 3) exhibited two peaks: first peak in the range of 300 to $310^{\circ} \mathrm{C}$ was labeled as $\alpha-C$, while the second peak at slightly higher temperature $\left(580-600{ }^{\circ} \mathrm{C}\right)$ was denoted as $\beta$-C, which exhibited less reactivity towards hydrogenation and oxidation than $\alpha$-C. It was concluded that different types of carbonaceous species played different roles in the dry reforming of methane. $\beta-C$ being less reactive was referred to as a major contributor in the deactivation of the catalyst. However, $\alpha-C$ was increased with the proceeding of dry reforming reaction. This linear relation leads to the conclusion that $\alpha-C$ may serve as reaction intermediate [53].

XPS studies for $\mathrm{NiO} / \gamma-\mathrm{Al}_{2} \mathrm{O}_{3}$ revealed transition peaks of $\mathrm{C} 1 \mathrm{~s}$ at 284.4-284.8, 286.4, 289.4 and ascribed to $-\mathrm{C}-\mathrm{C}-, \mathrm{C}-\mathrm{O}-\mathrm{C}$. 


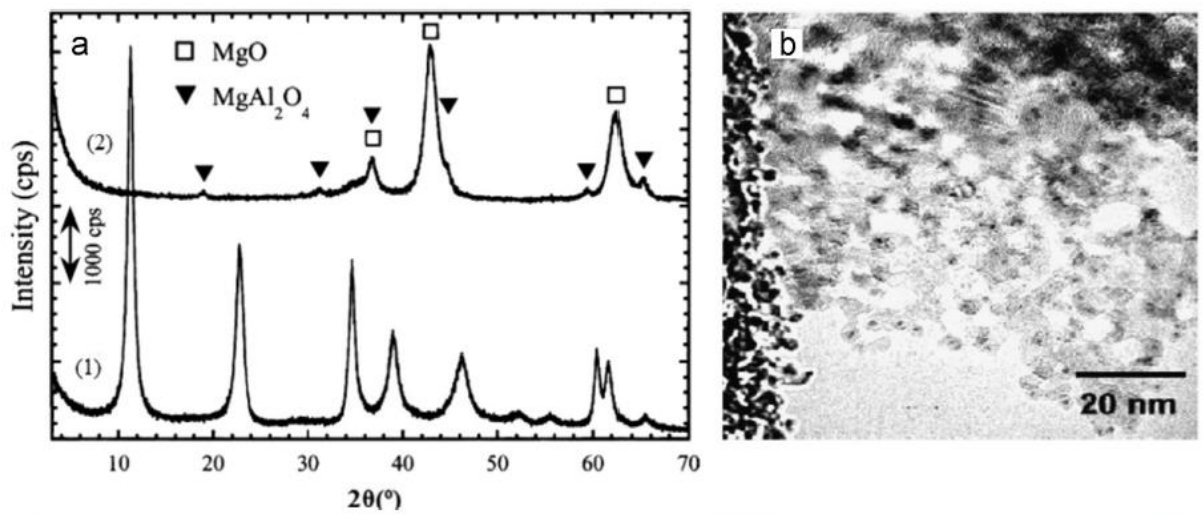

Fig. 4. (a) XRD profiles of the catalyst (1) before and (2) after activity test and (b) TEM image of the catalyst after the activity test [59].

$\mathrm{CO}^{3-}$ species, respectively. These species were assigned to different morphologies such as $\mathrm{C}-\mathrm{O}-\mathrm{C}, \mathrm{CO}^{3-}$ describes amorphous carbon while $-\mathrm{C}-\mathrm{C}$ - described the formation of filamentous carbon leading to deactivation [54]. In terms of their reactivity, amorphous carbon is known to be more reactive and easily gasified, however graphitic carbon needed higher temperature to be oxidized [55]. The detailed study of various parameters and their influence over catalytic activity, stability and carbon deposition will be discussed in this review.

\section{Influence of parameters on catalytic activity}

Numerous variables, such as active metal, support, promoter, calcination temperature, reducing environment, preparation method, particle size, and the reactor selection affected the catalytic activity and carbon deposition. The following section will investigate the influence of those variables over catalytic activity; morphology of carbon deposited as well as provided the target product compositions.

\subsection{Influence of active metal on catalytic activity}

Dry reforming of methane has been investigated with noble ( $\mathrm{Rh}$, $\mathrm{Ru}, \mathrm{Pd}$ and $\mathrm{Pt}$ ) and non-noble metal (Ni, Co and $\mathrm{Fe}$ ) based catalysts [56]. Noble metal catalysts have drawn attention for their superior coking resistance, higher stability and activity especially for higher temperature applications $\left(>750^{\circ} \mathrm{C}\right)$ [57]. Hou et al. [58] investigated the effect of different noble metals (Rh, Ru, Pt, Pd and Ir) supported over alumina and concluded that noble metal (5 wt\%) supported catalysts lead to higher coking resistance and stability. The catalytic activity and stability trend of the catalysts was $\mathrm{Rh} / \alpha-\mathrm{Al}_{2} \mathrm{O}_{3}>\mathrm{Ru} / \alpha-$ $\mathrm{Al}_{2} \mathrm{O}_{3}>\mathrm{Ir} / \alpha-\mathrm{Al}_{2} \mathrm{O}_{3}>\mathrm{Pd} / \alpha-\mathrm{Al}_{2} \mathrm{O}_{3}>\mathrm{Pt} / \alpha-\mathrm{Al}_{2} \mathrm{O}_{3}$. The amount of carbon deposited ( $\mathrm{mg}$ cat/g cat $\mathrm{h}$ ) over these catalysts was $\mathrm{Pd} / \alpha-\mathrm{Al}_{2} \mathrm{O}_{3}(4.9)$, and rest of them showed no carbon deposition $\mathrm{Ru} / \alpha-\mathrm{Al}_{2} \mathrm{O}_{3}, \mathrm{Rh} / \alpha-$ $\mathrm{Al}_{2} \mathrm{O}_{3} \mathrm{Ir} / \alpha-\mathrm{Al}_{2} \mathrm{O}_{3}$ and $\mathrm{Pt} / \alpha-\mathrm{Al}_{2} \mathrm{O}_{3}(0.00)$. The lower stability of Pt and Pd supported catalysts can be ascribed to the sintering of the metal particles at higher reaction temperatures. Tsyganok et al. [59] investigated the effect of incorporation of noble metals ( $\mathrm{Ru}, \mathrm{Rh}, \mathrm{Pt}$, $\mathrm{Pd}$, Ir and $\mathrm{Au}$ ) over $\mathrm{Mg}-\mathrm{Al}$ layered double hydroxides and reported higher catalytic activity and stability for $\mathrm{Ru} / \mathrm{MgAlO}{ }_{x}, \mathrm{Rh} / \mathrm{MgAlO}{ }_{x}$ and $\mathrm{Ir} / \mathrm{MgAlO}_{x}$. However, the catalytic activity and stability for Pd, Pt and Au catalysts were such as: $\mathrm{Pd} / \mathrm{MgAlO}{ }_{x}>\mathrm{Pt} / \mathrm{MgAlO}{ }_{x}>\mathrm{Au} / \mathrm{MgAlO}_{x}$. The coke deposition (wt\%) in the decreasing trend over these catalysts was $\mathrm{Pd} / \mathrm{MgAlO}_{x}(102.9)>\mathrm{Au} / \mathrm{MgAlO}_{x}(41.4)>\mathrm{Pt} / \mathrm{MgAlO}_{x}$ (5.5) > Ir/ $\mathrm{MgAlO}_{x}(4.9)>\mathrm{Rh} / \mathrm{MgAlO}_{x}(1.9)>\mathrm{Ru} / \mathrm{MgAlO}_{x}$ (1.3). The catalytic activity and stability of the catalysts matched with the coke

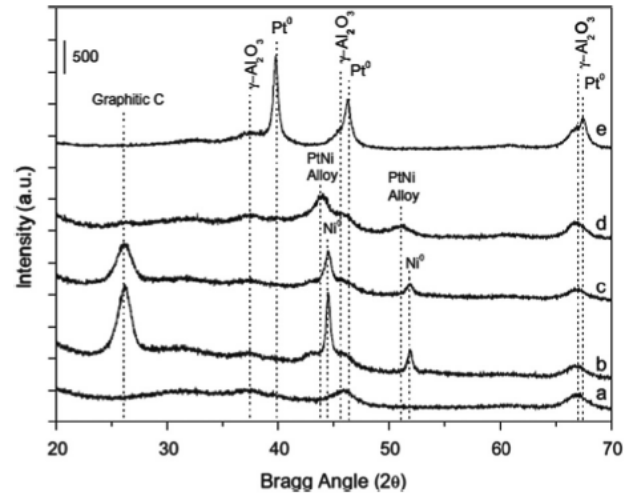

Fig. 5. XRD profiles for alumina support (a) and spent catalysts: (b) $4 \mathrm{Ni}^{2} / \mathrm{Al}_{2} \mathrm{O}_{3}$, (c) $0.04 \mathrm{Pt} 4 \mathrm{Ni} / \mathrm{Al}_{2} \mathrm{O}_{3}$, (d) $0.4 \mathrm{Pt} 4 \mathrm{Ni} / \mathrm{Al}_{2} \mathrm{O}_{3}$, and (e) $0.4 \mathrm{Pt} / \mathrm{Al}_{2} \mathrm{O}_{3}[64]$.

deposition trend. The higher catalytic activity and lower carbon deposition exhibited by Ru supported catalysts can be explained on the basis of X-ray diffraction (XRD) and transmission electron microscopy (TEM). XRD profiles (Fig. 4a) depicting the structure of catalyst before (1) and after (2) dry reforming of methane at $800{ }^{\circ} \mathrm{C}$ for $50 \mathrm{~h}$. The spent catalyst indicates the presence of $\mathrm{MgO}$ and $\mathrm{MgAl}_{2} \mathrm{O}_{4}$ and the absence of metallic Ru was noticed, which indicated that metal supported in the form of small particles. This conclusion was verified by TEM image (Fig. 4b) that showed the presence of highly dispersed and smaller metal particles around $1.5 \mathrm{~nm}$. The presence of highly dispersed and smaller particle size assisted in the reduction of carbon deposits, agglomeration and sintering. The ability of $\mathrm{Ru}$ to completely eliminate or reduce carbon deposition to a minimal level also matches with the above study [58].

However, noble metals with their superior carbon deposition resistance and in certain studies produced higher catalytic activities cannot be applied on the industrial scale due to their highcost [60]. In this scenario, non-noble metals ( $\mathrm{Ni}, \mathrm{Co}, \mathrm{Fe}$ ) become a suitable alternative for the industrial application due to low cost $[31,56]$. Hou et al. [58] incorporated different active metals ( $\mathrm{Rh}, \mathrm{Ru}$, $\mathrm{Pt}, \mathrm{Pd}, \mathrm{Ir}, \mathrm{Ni}$ and $\mathrm{Co}$ ) over alumina and the influence of noble metals ( Rh, Ru, Pt, Pd, Ir) on the coking resistance ability of the catalyst has been explained above. The comparison of noble (Rh, $\mathrm{Ru}, \mathrm{Pd}, \mathrm{Ir}$ and $\mathrm{Pt}$ ) and non-noble ( $\mathrm{Ni}$ and $\mathrm{Co}$ ) metal catalysts showed higher catalytic activities of $\mathrm{Ni}$ and Co catalysts compared 
to the noble metal supported catalysts. However, the higher coke deposition (mg cat/g cat h) for $\mathrm{Ni} \mathrm{(24.0)}$ and Co (49.4) catalysts indicate their poor coke resistance ability compared to noble meta catalysts. Deactivation arising from the coke deposition is the major obstacle in the application of Ni-based catalyst [61]; however, it can be overcome by the addition of alkali or alkaline dopants, application of supports with basic characteristics, or the development of highly dispersed Ni catalysts $[60,62]$. Moreover, the addition (small amounts) of noble metals ( $\mathrm{Rh}, \mathrm{Ru}, \mathrm{Pd}$, and Pt to Ni produced catalysts with affordable cost having good catalytic properties and lower sensitivity to carbon deposition [63].

Hou et al. [58] investigated the modification effect of noble metal (Rh) over Ni catalyst supported over mesoporous alumina. The Ni catalyst without Ru addition exhibited higher coke formation rates (17.2 $\mathrm{mg}$ coke/mg cat h) and lower methane (62.0\%) and carbon dioxide $(68.0 \%$ ) conversions. However, with the addition of small amount of Rh, Rh-Ni catalyst exhibited higher catalytic and no coke deposition was detected. This higher stability and activity was attributed to the synergic effect of $\mathrm{Rh}$ and $\mathrm{Ni}$, which lead to the formation of $\mathrm{Rh} \mathrm{Ni}$ cluster. Gracia et al. [64] reported that bimetallic catalyst $\left(0.4 \mathrm{Pt}-\mathrm{Ni} / \gamma-\mathrm{Al}_{2} \mathrm{O}_{3}\right)$ exhibited the highest activ ity (69\% methane conversion) compared to monometallic $4 \mathrm{Ni} / \gamma$ $\mathrm{Al}_{2} \mathrm{O}_{3}(60 \%)$ and $0.4 \mathrm{Pt} / \gamma-\mathrm{Al}_{2} \mathrm{O}_{3}(65 \%)$ catalysts. The highest catalytic activity was associated with the formation of $\mathrm{Pt}-\mathrm{Ni}$ alloy, which has higher Pt content on its surface and leads to the production of smaller metal particle size $(10 \mathrm{~nm})$ than monometallic Ni catalysts $(25 \mathrm{~nm})$. The graphitic carbon peak in Fig. 5 has been noticed to decrease with the increase of Pt content $(0.04-0.4)$ in $\mathrm{Ni} / \gamma-\mathrm{Al}_{2} \mathrm{O}_{3}$ catalyst, moreover, the study indicated lower carbon deposition $(6 \mathrm{wt} \%)$ for bimetallic catalyst $\left(0.4 \mathrm{Pt}-\mathrm{Ni} / \gamma-\mathrm{Al}_{2} \mathrm{O}_{3}\right)$ compared to the monometallic $\left(\mathrm{Ni} / \gamma-\mathrm{Al}_{2} \mathrm{O}_{3}\right)$ catalyst (45 wt\%). This indicates that addition of noble metals to $\mathrm{Ni}$ catalyst leads to the reduction of carbon deposition and produced smaller particle size compared to monometallic Ni catalysts.

The highest catalytic activity of bimetallic catalyst was also proved by another study [65], which reported higher methane conversion $(80 \%)$ for $\mathrm{Ni}-\mathrm{Co} / \mathrm{MgO}-\mathrm{ZrO}_{2}$ compared to monometallic $\mathrm{Ni}(70 \%)$ and $\mathrm{Co}(71 \%)$. It was attributed to the better metal dispersion, smaller particle size and the synergic effect between $\mathrm{N}$ and Co. Similarly, an addition of Rh [66] and Pt [67] to Ni supported on $\mathrm{SiO}_{2}$ [66] and ZSM-5 [67] indicated higher methane conversion $84 \%$ and $28 \%$, respectively, compared to monometallic $\mathrm{Ni} / \mathrm{SiO}_{2}(72 \%)$ and $\mathrm{Ni} / \mathrm{ZSM}-5$ (25.8\%). Another study reported that a combination of $\mathrm{Ni}$ and $\mathrm{Pd}$ exhibited better catalytic activities compared to Ni or Pd alone [68]. Horvath et al. [69] investigated $\mathrm{Ni}, \mathrm{Ni}-\mathrm{Rh}$ and $\mathrm{Ni}-\mathrm{Co}$ supported on $\mathrm{CeZr}$ and reported that bimetallic catalysts $(\mathrm{Ni}-\mathrm{Rh} / \mathrm{CeZr}$ and $\mathrm{Ni}-\mathrm{Co} / \mathrm{CeZr})$ showed stable catalytic activities compared to Ni/CeZr. The addition of Mo [70] and Pt [71] to Ni supported on mesoporous materials SBA-15 [70] and MCM-41 [71] showed higher activities compared to Ni/SBA-15 and Ni/MCM-41. The role of active metals in the enhancement of catalytic activity is listed in Table 1.

The comparison of $\mathrm{Ni}$ and $\mathrm{Co}$ catalysts supported on $\mathrm{Al}_{2} \mathrm{O}_{3}$ having similar preparation method (sol-gel) and reactor type (fluidized bed) exhibited higher catalytic activities for $\mathrm{Ni} / \mathrm{Al}_{2} \mathrm{O}_{3}$ compared to $\mathrm{Co} / \mathrm{Al}_{2} \mathrm{O}_{3}[72,73]$. The higher catalytic activity and stability can be attributed to the higher surface area $\left(216 \mathrm{~m}^{2} / \mathrm{g}\right)$ smaller particle size $(10.5 \mathrm{~nm})$ and higher dispersion $(9.5 \%)$ of $\mathrm{Ni}$ based catalyst; however, the role of slightly higher reaction temperature $\left(800^{\circ} \mathrm{C}\right)$ cannot be neglected. Similar results were reported by another study which reported higher catalytic activity and stability of $\mathrm{Ni} / \alpha-\mathrm{Al}_{2} \mathrm{O}_{3}$ catalyst compared to $\mathrm{Co} / \alpha-\mathrm{Al}_{2} \mathrm{O}_{3}$ catalyst due to the higher coke resistance ability of Ni catalyst compared to Co catalyst and the results are explained above for this study [58]. Another study investigating the effect of monometallic ( $\mathrm{Ru})$ and bimetallic $(\mathrm{Ru}-\mathrm{Ce})$ catalysts supported on $\mathrm{Al}_{2} \mathrm{O}_{3}$ indicated that the addition of a second metal on Ru enhanced the initial catalytic activity; however the stability of the catalysts were not studied in this article [88]. The study of the monometallic (Ni) [75], bimetallic catalyst $\left(\mathrm{Ni}-\mathrm{CeO}_{2}\right)$ [76] and noble metal (Pt) supported on $\mathrm{ZrO}_{2}$ [77] exhibited higher catalytic activities for the $\mathrm{Pt} / \mathrm{ZrO}_{2}$ [77] catalyst. The investigation on catalysts $\mathrm{Rh}[78]$ and Pt [79] supported on $\mathrm{ZrO}_{2}$ at same reaction and preparation conditions showed higher methane conversion (83\%) for $\mathrm{Pt} / \mathrm{ZrO}_{2}$ compared to $\mathrm{Rh} / \mathrm{ZrO}_{2}$ (65.9\%).

The study of the catalyst $\mathrm{NiO} / \mathrm{MgO}$ [80], $\mathrm{Co} / \mathrm{MgO}$ [81] and $\mathrm{Pt}-\mathrm{CeO}_{2}-\mathrm{ZrO}_{2} / \mathrm{MgO}$ [83] exhibited higher catalytic activity for $\mathrm{NiO} / \mathrm{MgO}$ compared to other catalysts although its stability was not high as in the case of $\mathrm{Pt}-\mathrm{CeO}_{2}-\mathrm{ZrO}_{2} / \mathrm{MgO}$ but it was fair enough to be regarded as a suitable catalyst due to its low cost. The comparison of monometallic $(\mathrm{Ni})$ and bimetallic $(\mathrm{Pt}-\mathrm{Ni})$ catalysts supported on $\mathrm{MgO}-\mathrm{SiO}_{2}$ exhibited the higher catalytic activity for the bimetallic catalyst [82]. The incorporation of different active metals on the ceria-zirconia mixture revealed that $\mathrm{Ni} / \mathrm{CeZr}$ [84] produced better catalytic activities compared to $\mathrm{Ni} / \mathrm{Ce}_{0.75} \mathrm{Zr}_{0.25} \mathrm{O}_{2}$ and $\mathrm{Ni}-\mathrm{Rh} / \mathrm{Ce}_{0.75} \mathrm{Zr}_{0.25} \mathrm{O}_{2}$ [85]. Similarly, studies for $\mathrm{Ni}[86,87]$ and $\mathrm{Ni}-\mathrm{MgO}$ [87] supported on $\mathrm{Ce}_{0.75} \mathrm{Zr}_{0.25} \mathrm{O}_{2}$ [86] and $\mathrm{Ce}_{0.8} \mathrm{Zr}_{0.2} \mathrm{O}_{2}$ [87] exhibited higher catalytic activities and enhanced stability for $\mathrm{Ni}-\mathrm{MgO} / \mathrm{Ce}_{0.8} \mathrm{Zr}_{0.2} \mathrm{O}_{2}$. The catalytic activity of $\mathrm{Ni} / \mathrm{Ce}_{0.75} \mathrm{Zr}_{0.25} \mathrm{O}_{2}$ was almost equal to $\mathrm{Ni}-\mathrm{MgO} / \mathrm{Ce}_{0.8} \mathrm{Zr}_{0.2} \mathrm{O}_{2}$, however, the addition of $\mathrm{MgO}$ to $\mathrm{Ni}$ lead to the increased stabilities $(200 \mathrm{~h})$. The incorporation of different monometallic $[90,91]$ and bimetallic catalysts $[90,91]$ in mesoporous support (MCM-41) leads to the conclusion that bimetallic catalysts produced better catalytic activities and stability compared to monometallic. However, another study proves otherwise and the catalytic activity of $\mathrm{Ni} /$ MCM-41 was higher than the above discussed articles, whereas, it can be attributed to the higher reaction temperature $\left(750{ }^{\circ} \mathrm{C}\right)$ [89]. The comparison of various studies for monometallic (Ni) [92] and bimetallic ( $\mathrm{Ni}-\mathrm{Mo}$ ) [93] catalysts supported by mesoporous support (SBA-15) exhibited higher catalytic activities for the bimetallic catalyst $\mathrm{Ni}-\mathrm{Mo} / \mathrm{SBA}-15$. This was attributed to the smaller particle size, higher specific surface area, strong metal support interaction and it was concluded that Mo has significant influence in effectively reducing the carbon deposition [70,93].

The incorporation of the various active metals (Ni [82,94], Rh [78]) and their combinations ( $\mathrm{Ni}-\mathrm{Ce})[95]$ on $\mathrm{SiO}_{2}$ exhibited higher catalytic activity and stability for the bimetallic catalyst ( $\mathrm{Ni}-\mathrm{Ce} /$ $\mathrm{SiO}_{2}$ ). The investigation of various active metals ( $\mathrm{Ni}$ [74], Rh [78] and $\mathrm{Ru}[57,88])$ supported on $\mathrm{CeO}_{2}$ exhibited higher catalytic activity ( $90 \%$ methane conversion) for $\mathrm{Ru} / \mathrm{CeO}_{2}$, however stability data for this study is missing. Even the higher reaction temperature in case of $\mathrm{Rh} / \mathrm{CeO}_{2}$ did not improve the catalytic activity compared to $\mathrm{Ru} / \mathrm{CeO}_{2}$ (lower reaction temperature). Monometallic catalyst (Rh, Ni, Pd and Ce) supported on Al-pillared layered clay (PILC) exhibited comparable catalytic activities for $\mathrm{Rh}$ and $\mathrm{Ni}$ (88\% and $85 \%$ methane conversion, respectively), while Rh-based catalyst showed lower carbon deposition (0.1 wt\%) compared to the $\mathrm{Ni}(25.6 \mathrm{wt} \%)$ catalyst. However, Pd and Ce-based catalysts showed much lower methane conversion (17\% and $47 \%$, respectively) compared to $\mathrm{Rh}$ and $\mathrm{Ni}$ catalysts [98]. The addition of $\mathrm{Ru}[60$ ] and $\mathrm{Pt}$ [99] to $\mathrm{Ni}$ supported on silica, $\mathrm{H}-\mathrm{ZSM}-5$ [60], $\alpha-\mathrm{Al}_{2} \mathrm{O}_{3}, \alpha-\mathrm{Al}_{2} \mathrm{O}_{3}-\mathrm{ZrO}_{2}$ and $\mathrm{ZrO}_{2}$ [99] lead to the superior catalytic activities compared to the monometallic catalyst (Ni), which was attributed to the higher dispersion and synergy between the metals. The investigation of the non-noble metals addition $(\mathrm{Co}, \mathrm{Fe}, \mathrm{Cu}$, or $\mathrm{Mn})$ to $\mathrm{Ni}$ showed higher catalytic activity for $\mathrm{Ni}$ - Co compared to monometallic and other bimetallic combinations [49]. Takanabe et al. [100] and Xu et al. [101] concluded that the $\mathrm{Ni}-\mathrm{Co}$ catalyst supported on $\mathrm{TiO}_{2}$ and $\gamma-\mathrm{Al}_{2} \mathrm{O}_{3}$ exhibited highest catalytic activities compared to monometallic (Ni, Co) catalysts. Similarly, $\mathrm{Rh}-\mathrm{Ni}$ catalyst supported on $\mathrm{CeO}_{2}-\mathrm{Al}_{2} \mathrm{O}_{3}$ [63], BEA zeolite [102] and boron nitride (BN) [103] resulted in higher catalytic

Link to Full-Text Articles :

http://www.sciencedirect.com/science/article/pii/S1364032115001148 